\title{
Viták az orvosnők képzéséről a XIX. század második felében
}

\author{
Kéri Katalin dr.
}

Pécsi Tudományegyetem, Bölcsészettudományi Kar, Pécs

\begin{abstract}
A „hosszú XIX. század” hazánkban is az intézményesült oktatás kiterjesztésének ideje volt. Az iskolai lánynevelés és nôi múvelődés különösen a dualizmus korszakában bontakozott ki, tágabban a társadalmi, politikai, gazdasági változásoknak, szúkebb értelemben az 1868-as, a kötelező népoktatás tárgyában hozott törvénynek köszönhetően. Ennek nyomán 6 és 12 éves kor között nemtől, felekezeti, nemzetiségi hovatartozástól függetlenül minden gyermeknek elemi iskolába kellett járnia. A törvénynek köszönhetôen az írni-olvasni tudók aránya a fiatalabb népesség körében látványosan javult, ez megalapozta a közép- és felsőoktatás fejlesztését. A század második felében az egyetemi felvétel feltétele az osztrák mintára 1849-ben kiadott, az 1850-51-es tanévtől életbe lépő Organisationsentwurf által bevezetett érettségi vizsga volt, ez azonban csak a fiúgimnáziumok növendékeinek volt elérhető a századfordulóig [1].
\end{abstract}

Az 1870-es, 1880-as években élénk viták kezdődtek a lányok és nők középiskolai és egyetemi képzésének lehetőségéről. Ez utóbbi vonatkozásában leginkább az tárható fel a korabeli sajtótermékekből és más forrásokból, hogy a nók orvosi képzésének kérdése állt a középpontban. Ezt az is nyomatékosította, hogy 1878-ban az Osztrák-Magyar Monarchia megszállta Boszniát, és a terület kormányzójává kinevezett Kállay Benjámin (1839-1903) úgy gondolta, hogy a muszlim női lakosság számára szükséges volna az orvosnők alkalmazása, ennek érdekében álláspályázatokat is hirdetett doktornók számára $[2,3]$. Tanulmányunk alapját az orvosnók képzéséről szóló, hazai nyomtatott forrásrészletek feltárása és elemzése adja. A feltárt kútfőkboól egyértelmúen látszik, hogy a cikkírók jelentôs része az 1890-es évekig elvetette a nők orvosi (egyetemi) képzésének lehetôségét, hivatkozva a női nem hagyományos szerepeire, a női erkölcsök védelmére, a nők és férfiak testi és szellemi értelemben vett különbségeire. A sajtótermékek között az Orvosi Hetilap az egyik olyan ritka lap volt, amely már 150 évvel ezelótt, 1869-70-ben az orvosnők képzése mellett érvelt. A lap akkori (alapító) főszerkesztője, Markusovszky Lajos (1815-1893) külföldi példákra és tudományos eredményekre alapozva fejtette ki másfél száz év távlatából nézve is korszerú gondolatait a témáról.

\section{Az előzmények: reformkori szerzők a nők egyetemi képzése mellett}

Magyarországon már a XIX. század első felében felvetődött a nők egyetemi képzésének kérdése. Nyíry István (1776-1838) sárospataki természettudós, matematikus tanár Nőjogtan [4] címmel készített egy, sok más terület mellett a nők felsőfokú képzésének kérdését is érintő értekezést.

A polihisztor Nyíry 1831-től volt az MTA levelező, 1832-től rendes tagja a Matematikai Osztályban, 1836tól pedig saját kérésére a második, Nyelvtudományi, Philosophiai és Történetírási Osztályba helyezték át. Valószínúleg ebben az idóben született fent említett múve. Ennek 29 . \$-a, a Nới tudományosság és hivatalok címú rész tartalmazza azt az azóta sokat idézett szövegrészt, hogy „a' szépnem mind a' tudományokra, mind a' gyakorlásokra igen alkalmatos. Miért engedik tehát a' felsőbb akademiai 's egyetemi tanulás' pályáit tőlök elzárni? Vagy, ha a' pajkos ifjakkal tanulni nem akarnak, miért nem nyitottak magoknak mind eddig is a' tudós és mívelt europai asszonyságok felsőbb tudományos intézetet 's karokat? Melly nagy előmenetellel dolgoznának a' tudományok' mezején, világos onnan, hogy a' tudományok' rendszeres hallgatásain kívúl is, önkiképzéssel, nagy lépéseket tesznek a' mennyiségi 's minemüségi tudományokban, azokban, mellyekben az érzés és képzés föviseletüek. (...) Úgy látszik azért, ha rendszerint nyitva volnának a' felsőbb tudományok' hajlékai a' szépnem előtt, közúlök minden tudományokban remek elmék állhatnának elő...” [4: 126]. Mû́ve ugyan csak kevéssel nyitott tágabb teret a nők múvelődési lehetőségeinek tekintetében, mint számos kortársának írásai, ám fentebb idézett gondolatai és értekezésének záró sorai, amelyekben szükséges feladatként jelölte meg a társadalmak átalakításához kapcsolódóan a nók helyének és szerepének, illetve jogainak átgondolását is, mégis utat mutatott a nők tanulási, múvelődési jogaiért őutána fellépők számára.

Valószínúleg 1848 áprilisában keletkezett az a négy fó követelést magában foglaló kiáltvány, amelyet Teleki Blanka pesti leánynevelő intézetének hét növendéke szerkesztett (vélhetően tanáruk, Vasvári Pál biztatására 
és segítségével). Ennek első pontja (mint a nők egyenlősítésének sarkalatos kérdése) így hangzott: „... kívánjuk, 1. Hogy az egyetemben nők is tanulhassanak" [5]. Teleki Blanka ugyanezt a kívánságot fogalmazta meg egy akkoriban írt (szintén kéziratban maradt) cikkében [6]. A szabadságharc bukása után viszont évtizedekre háttérbe szorult ez a kérdés Magyarországon. A lányok közép(és gyakran ezzel összefüggésben felső-) fokú tanulmányairól kialakult viták a dualizmus idején, különösen is az 1880-as évektől élénkültek meg.

\section{Vélemények az orvosnőkről a dualizmus első felében}

Az 1867 után kiadott magyar könyvekben és újságokban számos írás foglalkozott azzal, hogy a nők alkalmasak-e a tanulásra, képesek-e egyáltalán arra, hogy tudományos pályára lépjenek. A témáról szólók eleinte az „egyetem” fogalma alatt csakis az orvosi karokat értették. Sokan nem láttak előre a jövőbe, az 1870-es években a legtöbb aggodalmaskodó szerző még úgy gondolta, hogy a nők csak az orvosi pályára törekednek, ezért ettôl próbálták őket „megóvni”.

A korszak ismert írónője, Beniczky Irma (1828-1902) például azzal érvelt, hogy a nők fizikailag nem elég erősek ahhoz, hogy nehéz mútéteket végezzenek, és családi kötelezettségeik miatt úgysem lenne elegendő erejük az orvosi hivatás gyakorlásához. Azt is megjegyezte még, hogy amúgy sem volnának olyan páciensek, akik orvosnővel gyógyíttatnák magukat [7]. Herczeghy Mór (18151884), a világlátott orvos hasonlóan vélekedett majd egy évtizeddel később is. Ő úgy gondolta, hogy a nők ugyan tanítónak sikerrel alkalmazhatók, de orvosi, múvészi és tudományos pályára nem valók [8].

A nók egyetemi/orvosi képzésével kapcsolatosan a korabeli hazai orvostársadalom lapja, az 1857-ben alapított Orvosi Hetilap nagyon korán, már 1869-70-ben közölt egy cikksorozatot, három részben szólva arról, hogy való-e a nőknek az orvosi pálya [9]. A minden túlzástól mentes, korát megelőzően modern, tárgyilagos és józan hangvételü cikkek szerzője a lap föszerkesztóje, Markusovszky Lajos orvos volt, aki 1867-től a Vallás- és Közoktatásügyi Minisztériumban az orvosképzési, majd később valamennyi egyetemi ügy előadójaként tevékenykedett. Nyitó írásában ő azt fogalmazta meg, hogy időszerű errốl a kérdésról beszélni, hiszen Amerikában már gyakorolhatják a nők ezt a hivatást, Franciaországban pedig egyre többet cikkeznek erről, miként jelezte, elsősorban amiatt, mert az algériai gyarmati területeken a muszlim nőknek szükségük volna jelentôs számú orvosnőre. A cikkíró úgy vélte, hogy Magyarországon is egyre több és több nő kényszerül valamilyen pénzkereseti forrás után nézni, és úgy gondolta, hogy biztosan több, korábban csak a férfiak által betöltött foglalkozási ágban fognak megjelenni. A nők orvosi pályára kerülését szerinte az is gyorsítani fogja, hogy a magyar nőtársadalom is igényli (ahogyan fogalmazott: főleg szülésnél és ivarszervi bán- talmak esetén) a képzett orvosnők segítségét. Cikkeiben - hangsúlyozva a hozzáértés, a tájékoztatás szerepét a szenvedélyes és igazságtalan vélemények hangoztatása helyett - arra kereste a választ, hogy alkalmasak-e a nók testi és elmebeli tulajdonságaiknál fogva az orvosi pályára, remélhető-e, hogy alkalmazni is fogják óket, ha tanulnak, és hogy a férfiakkal együtt vagy külön kell-e képezni óket. Markusovszky sorra vette azokat a korabeli véleményeket, amelyek a nók és férfiak együttes egyetemi képzése ellen megfogalmazódtak, és ezeket (külföldről vett) példákkal sorra megcáfolta. Nem tartotta megalapozottnak például azt az előfeltevést, hogy ha a két nem együtt tanul, akkor a férfiak „mindennemú pajzánságokra vetemednének, mi a tanhelyiségeken a jó rendet megzavarná; míg más részről a nők, kik magukat az ellenük intézett incselkedések ellenében védeni kényteleníttetnének, szerénytelenekké válnának, mi nem egyeztethető meg azon komolysággal és erkölcsi tisztasággal, mivel az orvosoknak birniok kell, hogy hivatásuknak lelkes odaadással, s mindemellett teljes méltósággal éljenek" [9: 555]. Elutasította azt az állitást is, hogy ha a férfi és a nói hallgatók egy teremben boncolnak, akkor a férfiak undort kezdenek érezni kolléganőik iránt. Ugyanakkor megemlítette, hogy Párizsban a Société pour l'Instruction Médicale des Femmes (Társaság a Nők Orvosi Képzéséért) 1871-től külön képzést fog szervezni leendő női orvosok számára, akiket három éven át, heti három-három órában arabul és törökül is megtanítanak, hogy az orvosnők a gyarmati területeken a háremekben is tudják erősíteni a francia befolyást. Ezt követôen leírta a Társaság fóbb szabályait, valamint a nőhallgatók számára tervezett tantárgyak első évi francia programját. Ezt a cikksorozatot mindenképpen az orvosnóképzés mellett tudományosan érvelő, egyik legelső hazai forrásunkként tarthatjuk számon.

Az 1890-es évek elejére aztán Magyarországon is szélesebb körben felerősödtek a nők egyetemi képzését támogató hangok. 1891-ben a Nemzeti Nönevelés hasábjain [10] (és ezzel szinte párhuzamosan a Gyógyászat címú lap különlenyomatában is [11]) az író és kultúrpolitikus György Aladár (1844-1906) így írt az orvosnók képzéséről: „A nő, kit az emberi nyomor látása az orvosi pályára visz, ha értelme s tapintata elegendő, annyit érhet e téren, mint hasonló tehetségü férfiú ... minden nőt csak azért, mert nő, az orvosi pályától eltiltani nem lehet, nem szabad" [10:341]. A szerző feltette a kérdést: vajon múlékony kortünet-e mindössze az a törekvés, hogy a nők is bejussanak az egyetemekre? Ó így érvelt: „...miként az utazó ügynök s tengerész is lehet jóindulatú családapa, a tanítónő s orvosnő sem szúnik meg igazán nő lenni, ha neveltetése helyes s egyénisége nem félszeg" [10: 342]. Kiemelte, hogy orvosnókre amiatt is nagy szükség van Magyarországon is, mert sok (föként fiatal) nő - leginkább a középosztálybeliek - szemérmességből, félelemből nem fordul férfi orvoshoz, ha problémája van. György Aladár, a muszlim országok példáihoz hasonlóan, az orvosnők alkalmazásától a nő- és gyermek- 
gyógyászat eredményeinek jelentős javulását várta [10: 347]. Több korabeli szerzőhöz hasonlóan felemlegette ő is az 1879-ben Svájcban orvosi diplomát szerzett Hugonnai Vilma hazai kálváriáját, de nagy biztonsággal leszögezte, hogy „az első úttörő nem aratott sikert, de az eszme nálunk sem bukott el. Magyar orvosnő lesz bizonnyal, mert szükség van reá. Évről-évre olvassuk a lapokban, hogy egy-egy kiváló leány az elébe halmozódó nehézségek daczára, mily nagy sikerrel tette le az érettségi vizsgát. Oly gazdagok vagyunk-e tehetségekben, hogy az ily kiváló nók csak kuriózumok maradhatnak; hosszú évek fáradsága nyom nélkül tünhetik el? (...) Legyen bár kivételes a nőorvos helyzete, Magyarországban is kell lenni nőnek, ki hivatásszerúleg fog gyógyítással foglalkozni. Az igazság ereje nagy" [10: 348-349].

További neves szerzők a századvégen, György Aladárhoz hasonlóan, előadásaikban is népszerúsítették a nók egyetemre kerülésének gondolatát. A filozófus, irodalmár és tanár Maczki Valér (1847-1921) például csoportokba szedte az ellenérveket, és megpróbálta ezeket cáfolni. Szerinte az egyik ellenvetés az, hogy a nők egyetemi képzése „idegen találmány”. Válasza: „Azért, mert külföldön gondolkodnak és haladnak, Magyarországon nem kell erról lemondani" [12: 14]. A másik ellenérv mely szerint az egyetemi képzés ellenkezik a nő finomabb és gyengédebb szervezetével - szerinte azért hamis, mert a nó a történelem során folytonosan fizikai munkákkal is foglalkozott, földmúvelésben és egyéb nehéz munkákban vett részt. Azzal kapcsolatosan pedig, hogy a nők leszorítják a férfiakat a különböző pályákról, Maczki többször is hangsúlyozta, hogy a „versengésben” győzzön a jobb [12: 16]. 1892-ben az Élet címú lapban közzétettek egy írást Pulszky Polixénia (18571921) tollából, amely nagy vitát váltott ki a nőképzést illetően. A Pulszky Ferenc leányaként Londonban született, világlátott, a nőnevelés ügye iránt különösen érdeklődő hölgy az egyetemi képzéssel kapcsolatosan úgy vélte, hogy a nói gyerekorvosok, az ápolónók és a gyógyszerésznók képzése az egyetemeken megengedhető. Annyit azonban megjegyzett, hogy sebészek semmi esetre ne legyenek [13]. Késóbb ezzel szemben egy bizonyos „Julius” megjegyezte, hogy az nem indok a női sebészek ellen, hogy „ellenszenves, ha a nő késsel emberhúsba vág” [14]. Julius szerint a teljes emancipáció a felsőoktatás terén is szükséges, minden nő tanuljon azt, amit akar, éppen úgy, mint a férfiak.

A XIX. század második felének nagy változásai az orvosnőkkel kapcsolatos legtöbb kétséget valóban eloszlatták. Egyrészt az a tény, hogy a fejlődés hatására részterületekre bomlott az orvoslás, hozzájárult a nők pályára kerüléséhez. Ha valaki fizikumánál fogva nem volt alkalmas összetett operációk elvégzésére, az orvoslás egyéb ágaiban is talált munkát magának (nő- és gyermekgyógyászat, szemészet, ortopédia stb.). Másrészt pedig a megnövekedett népesség, a megváltozott higiéniai-közegészségügyi viszonyok és reformok már önmagukban is mind több és több orvost követeltek.

\section{A nyitás}

Az ellenlábasok figyelmeztetései ellenére kivétel nélkül valamennyi országban először az orvosi és a bölcsészeti karok nyíltak meg a nők előtt. Magyarországon 1895. december 19-én kelt Wlassics Gyula (1852-1937) kultuszminiszter 65719/1895. számú rendelete, mely megnyitotta a nők előtt a budapesti és a kolozsvári felsőfokú intézmények egyes egyetemi karainak a kapuját (a bölcsészeti és orvosi kart, valamint a gyógyszerészeti tanfolyamot) [15]. Jóllehet a miniszter valamennyi világi fakultást és a Múegyetemet is meg akarta nyitni, Ferenc József király csupán ezekre a karokra engedélyezte a nők belépését, az akkori miniszterelnök, Bánffy Dezső (1843-1911) pedig ellenezte ezt a rendeletet, mert nem értett egyet a nők egyetemekre való felvételével. (A miniszter pályáját, e rendeletének háttértörténetét is számos elsődleges forrásra támaszkodva, árnyaltan mutatta be múveiben Mann Miklós) [16, 17].

Az orvosképzést az első évben még egyetlen nőhallgató sem kezdte el, Hugonnai Vilma viszont már ekkor kérte zürichi oklevele honosítását, ami - a számára előírt három orvosgyakorlati szigorlat után - 1897. május 14én végre megtörtént [18: 31]. Az első újsághíradásokból is látszik, hogy eleinte azok a nők jelentkeztek az orvosi karra, akik korábban külföldön már folytattak egyetemi tanulmányokat. Schorr Matild például, aki Zürichben már 4 tanfolyamot végighallgatott az orvosi karon, az első nők egyike volt, akik itthon beiratkoztak az egyetemre [19]. Szendefi Ida, Königsberger Lea és Steinberger Sarolta (1875-1966) is külföldi tanulmányaik után kezdtek orvosi karra járni. Hármuk közül ez utóbbi volt az első olyan nő, aki itthon szerzett diplomát 1900-ban. Érdekes és fontos orvostörténeti adat, hogy 1902-ben ő írta meg három részben az orvosnők történetét az Orvosi Hetilap tudományos mellékletében, Mélanie Lipinska 1900-ban Párizsban kiadott múve nyomán [20]. A budapesti karon az orvosképzésnek az 1896-97-es, a gyógyszerészeti tanfolyamnak pedig az 1903-04-es tanévtốl voltak női hallgatói. A hallgatónók számaránya az egyetemi diákság körében a századfordulóig $1 \%$ alatt maradt, csupán az 1910-es évek elejére érte el a 7,5\%-ot, amikor is az intézménynek már 564, leginkább tisztviselói-értelmiségi családból származó nőhallgatója volt [21]. A nőhallgatók számának alakulásáról karonként, tanév szerinti bontásban adatokat közlő, a férfiak és a nők vizsgaeredményeit összevető és az 1913-14-es tanév tanári vizsgálatainak eredményeit is közlő alapmú [18: 93-106] már évtizedekkel ezelőtt megmutatta, hogy milyen dinamikusan nőtt a nőhallgatók száma, és hogy eredményeik egyáltalán nem maradtak el a férfiakéitól.

Napjainkban a hazai orvostársadalomnak már több mint 54\%-a nó; pályára kerülésük 150 évvel ezelőtti megalapozásához Markusovszky Lajos és az Orvosi Hetilap fontos és sokrétü, tudományosan megalapozott érvkészletet adott, mindezt pedig sok más vélemény és példa mellett a századfordulón megerősítette és visszaiga- 
zolta az első magyarországi orvosdiplomával praktizáló nő, Steinberger Sarolta doktornő szintén az Orvosi Hetilap mellékletében közölt cikksorozata és egész életmúve.

\section{Irodalom}

[1] Horánszky N. Organisationsentwurf is 150 years old. [150 éves az Organisationsentwurf.] Új Pedagóg Szle. 1999; 9: 61-72. [Hungarian]

[2] Kiss L. Female medical students in the servants' entrance, or medical history curiosities from the Hungarian history of emancipation. [Medikák a cselédbejáróban, avagy orvostörténeti kuriózumok az emancipáció magyarországi történetéből.] Lege Artis Med. 2009; 19: 358-360. Available from: http://www. elitmed.hu/upload/pdf/medikak_a_cseledbejaroban_avagy_orvostorteneti_kuriozumok_az_emancipacio_magyarorszagi_tortenetebol-3730.pdf [accessed: April 5, 2019]. [Hungarian]

[3] Kiss L. Rehabilitation of an "old fashioned" pathologist - Antal Genersich (1845-1918) died hundred years ago. [A ,vaskalapos" kórboncnok rehabilitálása - száz éve hunyt el Genersich Antal (1842-1918).] Orv Hetil. 2018; 159: 885-887. [Hungarian]

[4] Nyíry I. Women's law. [Nőjogtan.] In: A Magyar Tudós Társaság Évkönyvei 1834-1836. III. kötet, Buda, 1838; pp. 97-129. [Hungarian]

[5] A proclamation of female students on equality between women and men. [Leánytanulók kiáltványa a nők egyenjogúsága ügyében.] In: Fáy A, Vahot I, Karancs T, et al. The pioneers in history of Hungarian women's education. [A magyar nőnevelés úttörői.] Tankönyvkiadó, Budapest, 1962; p. 296. [Hungarian]

[6] Nagyné Szegvári K, Ladányi A. Women at universities I. Strug gles for women's university studies. [Nők az egyetemeken I. Küzdelmek a nők egyetemi tanulmányaiért.] Felsőoktatási Pedagógiai Kutatóközpont, Budapest, 1976; p. 8. [Hungarian]

[7] Beniczky I. The profession of women. [A nők hivatása.] Heckenast G., Pest, 1870; pp. 233-234. [Hungarian]

[8] Herczeghy M. The physical and spiritual nature of the woman. [A nő physikai és szellemi természete.] Budapest, 1883. [Hungarian]
[9] $\Delta$-६: Is the medical field suit for women? [Az orvosi gyakorlat nőknek való-e?] I-II-III. Orv Hetil. 1869; 13: 607-608., 1869; 13: 623-624, 1870; 14: 555-557. [Hungarian]

[10] György A. Women as doctoresses. [Nők mint orvosok.] Nemzeti Nőnevelés 1891; 12: 341-349. [Hungarian]

[11] György A. Women as doctoresses. [Nők mint Orvosok] Gyógyászat 1891; 30: 466-469. [Hungarian]

[12] Maczki V. Higher tasks of women's education. [A nőnevelés magasabb feladatai.] (é. n.) Fol Hung. 2466. OSzK, Kézirattár. [Hungarian]

[13] Pulszky P. For the women question. [A nőkérdéshez.] Élet 1892; 4: 149. [Hungarian]

[14] Julius. For the women question. [A nókérdéshez.] Élet 1892; 6: 237. [Hungarian]

[15] Ministerial order with number 1895: 65719. [1895: 65719. sz. miniszteri rendelet.] In: Magyarországi rendeletek tára 29. évf. VII-IX. f. Budapest, 1895; pp. 1680-1686. [Hungarian]

[16] Mann M. Gyula Wlassics. [Wlassics Gyula.] ELTE, BTK, Neveléstudományi Tanszék, Budapest, 1994. [Hungarian]

[17] Mann M. Women at university. [Nők az egyetemen.] História 1995; 4: 19. [Hungarian]

[18] Nagyné Szegvári K, Ladányi A. Women at universities I. Struggles for women's university studies. [Nók az egyetemeken I. Küzdelmek a nők egyetemi tanulmányaiért.] Felsőoktatási Pedagógiai Kutatóközpont, Budapest, 1976 [Hungarian]

[19] Misses at the university. [Kisasszonyok az egyetemen.] Pécsi Közlöny 1896; okt. 8: 2. [Hungarian]

[20] Steinberger S. History of doctoresses I-III. [Az orvosnők története I-III.] Gynaekologia. Tudományos melléklet az Orv Hetil. 2., 4. és 6. számához. 1902; május 11.: 36-41, 1902; szeptember 7.: 99-105, 1902; december 14.: 120-127. [Hungarian]

[21] Müller I. The social composition of the women students at the University of Budapest, 1896-1914. [A Budapesti Tudományegyetem nőhallgatóságának társadalmi összetétele, 1896-1914.] Korall 2001; 3-4: 203. [Hungarian]

(Kéri Katalin dr., Pécs, Ifjúság útja 6., 7626 e-mail: keri.katalin@pte.hu)

\section{"Amare et servire." \\ (Szeretni és szolgálni.)}

A cikk a Creative Commons Attribution 4.0 International License (https://creativecommons.org/licenses/by/4.0/) feltételei szerint publikált Open Access közlemény, melynek szellemében a cikk bármilyen médiumban szabadon felhasználható, megosztható és újraközölhetö, feltéve, hogy az eredeti szerző és a közlés helye, illetve a CC License linkje és az esetlegesen végrehajtott módosítások feltüntetésre kerülnek. (SID_1) 